\title{
Revenue-raising by UK Devolved Administrations in the Context of an Expenditure-based Financing System
}

\author{
DAVID HEALD and ALASDAIR MCLEOD
}

Devolution in the United Kingdom is asymmetric, both in size and scope. It extends to Scotland, Wales and Northern Ireland, but not, as yet, to England, which contains 84 per cent of the UK population. ${ }^{1}$ In addition, the powers available to, and the functions of, the devolved administrations are different in each case (though the financing arrangements are broadly the same).

In each case, political devolution (with elected assemblies) followed on a long period (again varying) of administrative devolution, whereby government departments specific to each territory ${ }^{2}$ were responsible for a wide range of functions, and operated with some degree of independence from UK departments. ${ }^{3}$ These prior arrangements have had a significant influence on the powers and functions of the devolved administrations, the asymmetries inherent in them having been largely carried forward.

Contemporary developments are rooted in the proposals of the Kilbrandon Royal Commission on the Constitution (1973), which resulted in legislation for Scotland and for Wales that was never brought into force. The 1979-97 Conservative governments were antagonistic to devolution and implementation had to await the election of a Labour government in 1997.

Financing devolved government is a broad topic, so this article concentrates on a limited number of issues. Specifically, the focus is upon the revenue-raising capacities of the UK devolved administrations in the context of the financing system that was implemented when the Scottish Parliament, the National Assembly for Wales and the Northern Ireland Assembly came into being in 1999. A discussion of revenue-raising has to be set in such a context, as otherwise there is likely to be confusion as to whether increased recourse to 'own financing' will affect the level of expenditure that can be incurred. This article examines the revenue-raising capacities of the devolved administrations and not the performance, relative to England, of the Scottish, Welsh and Northern Ireland economies. The latter clearly affects the former, but raises many issues outside its scope.

David Heald, University of Sheffield; Alasdair McLeod, University of Aberdeen

Regional and Federal Studies, Vol.13, No.4, Winter 2003, pp.67-90

PUBLISHED BY FRANK CASS, LONDON 
This article is structured as follows. The starting point is an overview of the main features of the UK devolved financing system. This examines the architecture of the expenditure side, which is shown to dominate the revenue side. The operation of the Barnett formula system, including the important convergence properties, is briefly explained. The importance of the local government financing system is emphasized in the subsequent discussion of the architecture of the revenue side. Attention then turns to policy at the UK level, in those aspects that are relevant to the operation of the devolved administrations. In the following section, the impact at the territorial level is considered, examining Scotland, Wales and Northern Ireland in turn. Then there is a discussion of the impact on England, outside the devolved financing system, but whose expenditure changes generate formula consequences for the territories. This leads on to an examination of the strengths and weaknesses of the contemporary UK system. An important strength is continuity from the pre-devolution arrangements. Criticisms of the system relate to inadequate transparency, geographical inequity and the absence of institutional machinery. Finally, we briefly summarize the main conclusions of this article.

\section{OVERVIEW OF THE UK DEVOLVED FINANCING SYSTEM}

\section{Architecture of the Expenditure Side}

One way of looking at the public expenditure system in the United Kingdom is to distinguish between two kinds of expenditure (Heald, 1994): expenditure undertaken on a UK basis, ${ }^{4}$ such as national defence and social security, and that undertaken on a country basis. Generally speaking, the first is undertaken by the UK government directly, though there are circumstances where the devolved administrations essentially act as agents for that government. The second is, in the territories, now the province of the devolved administrations - though, in most cases, the provision of services administered separately in each country predates devolution. ${ }^{5}$

Aggregate expenditure on the devolved services in each of the devolved territories is determined by what has come to be known as the Barnett formula, a system representing the continuation of the pre-devolution 'block' system which had been in place for 20 years (Heald, 1994). Allocation of these aggregates among the devolved public services is determined by the devolved administrations, and allocations for UK services administered by the devolved administrations are determined separately.

The Barnett formula is not a formal system of explicit equalization at country level, whether for resources or needs, of the kinds familiar from 
federal countries such as Australia, Canada and Germany. The pattern of demography and economic activity, however, means that an inevitable result of uniform UK policy on services that are not devolved, particularly social security payments, is substantial implicit territorial equalization.

In the case of separately administered expenditure, there are welldefined and internal funding systems within each of Scotland, Wales and Northern Ireland and indeed in England (though the UK government administers these). Important examples of such systems are: National Health Service (NHS) funding allocations; the allocation of Aggregate External Finance to local authorities; and the formula funding of universities and higher education institutions. Even before devolution, developments often took place in each country substantially in isolation from developments in the other countries. Post-devolution, these internal allocations have begun to attract more attention, particularly in relation to the NHS. In England, the formula funding of schools and further education colleges has attracted a great deal of controversy.

\section{Convergence Properties of the Barnett Formula System}

The present authors have published a series of papers on UK devolution finance, and results established there are stated, without full justification. A thorough explanation of the Barnett formula system after devolution appears in Heald and McLeod (2002a) and the mathematical properties of the Barnett formula are investigated in Heald (1996). In this article, the description and analysis of the Barnett formula system are restricted to those issues necessary to understand the technical and political context of revenue-raising. ${ }^{6}$

The most important feature of the devolved financing system is that it carried forward the Barnett formula system that had been introduced in connection with the devolution proposals in the 1970s and developed under administrative devolution. ${ }^{7}$ This is a striking example of what the Kilbrandon Royal Commission on the Constitution (1973), particularly in its Memorandum of Dissent, described as an expenditure-based system as opposed to a revenue-based system. Under the latter, the level of expenditure of a sub-national government depends upon its own revenueraising and borrowing capacities. Practical manifestations are not necessarily of pure form, and it should be noted how an ostensibly revenuebased system can be transformed into an (unacknowledged) expenditurebased one by the detailed operation of equalization systems. This is exactly what happened in Northern Ireland, under the 1921-72 period of devolution (Lawrence, 1965; Gibson, 1996).

In essence, under the Barnett formula, the aggregate changes in public expenditure in England on devolved services are calculated. (The aggregate 
is different for each of the territories since the coverage of devolved services is different in each). A proportionate increase, on the basis of the latest available population estimates, is then added to the existing provision for each of the territories. ${ }^{8}$ The original baseline for each of the territories was simply the existing provision for the appropriate services, at the time the formula was introduced.

In each of the territories, expenditure per head on devolved services is higher than in England. Since each territory receives the same increase, adjusted for population, as in England, the inevitable consequence of strict application is that the advantage in expenditure per head will decrease over the years, a phenomenon known as convergence. If relative populations remain constant, then expenditure per head in all three territories will converge asymptotically on that for England (Heald, 1994; Bell, Dow, King and Massie, 1996), though the fact that this condition was not met in practice attenuated convergence in the case of Scotland. ${ }^{9}$

The rate of convergence increases with the rate of expenditure growth as shown in Figure 1. The upper line shows the half-life - the number of years that it would take for the excess over England to decrease to half its value. Thus, if nominal expenditure in England were to grow constantly at 2 per cent a year, it would take 35 years for the per head differential to reach half its value, say from 10 per cent above or below to 5 per cent. At an expenditure growth rate of 8 per cent, the half-life is nine years. The lower line shows the time taken for expenditure per head 30 per cent higher (or lower) than in England to decrease to 20 per cent. Both lines show that the rate of convergence is steep at expenditure growth rates above about 6 per cent.

FIGURE 1

THE CONVERGENCE EFFECT OF THE BARNETT FORMULA
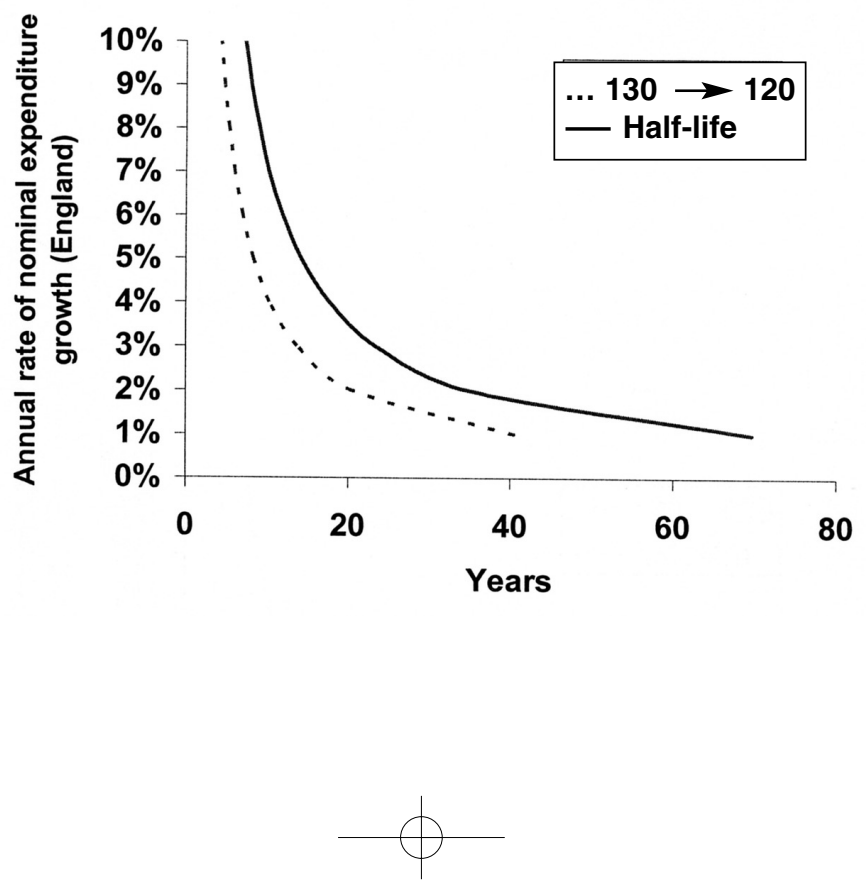
FIGURE 2

SCOTTISH IDENTIFIABLE EXPENDITURE, INCLUDING AND EXCLUDING SOCIAL SECURITY AND AGRICULTURE ETC. $($ UK=100) 1987/1988-1999/2000

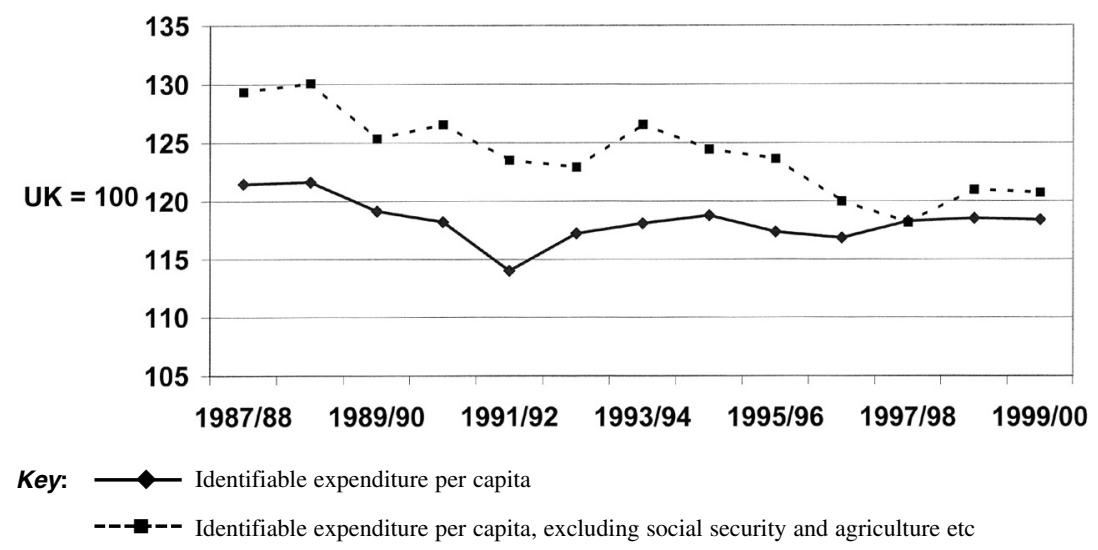

Data necessary to test for convergence are not in the public domain. ${ }^{10}$ If a consistent series were available, the present authors believe there would be evidence of some convergence, with the formula system having been more tightly operated after 1992 and with strong expenditure growth having occurred from 1999/2000 onwards. Some commentators have used the series on 'identifiable public expenditure' published annually in Public Expenditure: Statistical Analyses (Treasury, 2003b; Treasury, 2003c). However, this is not the correct expenditure aggregate on which to test for convergence as it contains much expenditure that is neither devolved nor formula-controlled.

Nonetheless, in the absence of better data, an impression of what is happening in Scotland can be derived from this identifiable expenditure series. Figure 2 reproduces a diagram first published by Goudie (2002, Figure 6). The index of identifiable expenditure per capita shows little trend. But when a rough adjustment is made by excluding both social security (operated on a GB basis, with Northern Ireland having a separate administration but essentially uniform benefits) and agriculture etc. (not formula-controlled and in practice driven by European Union policy), this index has dropped about ten points, from roughly 130 to 120 , over the period $1987 / 88$ to $1999 / 2000$.

The Barnett formula has been criticized, for opposite reasons, both in the territories and in the English regions (Bell and Christie, 2001). ${ }^{11}$ In the territories, it is seen as disadvantageous because of the inbuilt convergence. 
Indeed, the term 'Barnett squeeze' has acquired widespread circulation; and this has been quantified by Cuthbert and Cuthbert (2001). Any quantification of this sort, however, has to make assumptions about what the allocation would have been in the absence of the Barnett formula - and any such assumptions must be questionable (Midwinter, 2002a). Conversely, in the English regions, it is seen as a mechanism for perpetuating, unfairly, the pre-existing advantage in expenditure per head enjoyed by the territories.

Constitutional entrenchment of financing systems is impossible in the United Kingdom: indeed, the UK Parliament can suspend or abolish the devolved administrations. Whether this would be politically feasible clearly depends on politics, and such actions seem highly improbable with regard to the Scottish Parliament and the National Assembly for Wales. ${ }^{12}$ Paradoxically, the non-statutory Barnett formula has probably acquired more protection from the fact that the 1997 referendums in Scotland and Wales were fought on White Papers incorporating this mechanism than if the formula itself had been embodied in UK legislation, always amendable by the UK Parliament.

\section{Architecture of the Revenue Side}

The major financing for the devolved administrations is by means of central transfers. Indeed many commentators suggest that that this is the only source of funds except for the power, not used as yet, for the Scottish Parliament alone to vary the rate of income tax (the 'tartan tax') (Heald and Geaughan, 1997). But the picture is more complex. Devolved

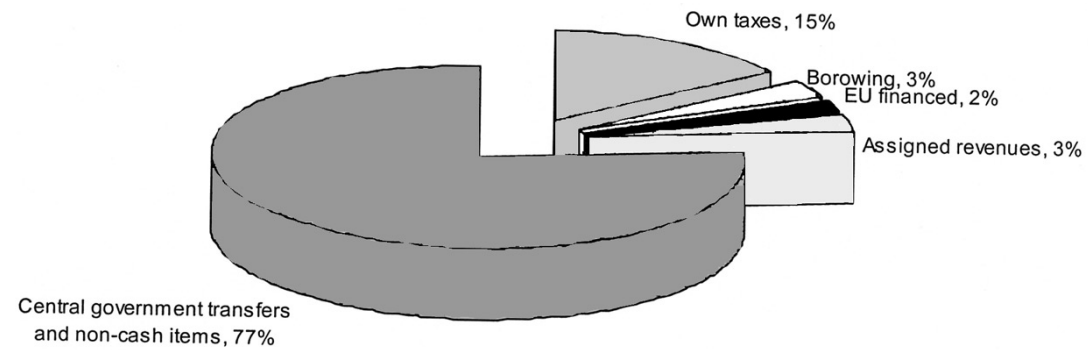

Sources: Scotland Office (2002); Treasury (2002b); and supplementary information from the Scottish Executive and the Convention of Scottish Local Authorities. 
administrations also receive European Union (EU) funds and an admittedly small - amount of assigned revenues.

Significantly, the devolved administrations also have some control over the local government finance system, though the details (explained further below) vary from territory to territory. A potential source of fiscal discretion for the devolved administrations relates to the transfers that they make to their respective local governments: for example, lower transfers and higher dependence on local taxes, or alternatively higher transfers and lower dependence on local taxes.

Taking the case of Scotland, Figure 3 analyses the financing in 2002/03 of an expenditure aggregate that includes the self-financed expenditure of local authorities. Figure 3 shows the percentage of revenues attributable to particular sources. Central government transfers and non-cash items account for 77 per cent. Own taxes represent 15 per cent, and assigned revenues (that part of National Insurance Contributions that is hypothecated to financing the NHS) represent 3 per cent. Finally, EU financing represents 2 per cent and borrowing 3 per cent. In 2002/03, the tartan tax was not used. In Figure 3, 'own taxes' refers to local government taxes, with there being a roughly 50:50 split between revenues from non-domestic rates (the business property tax) and revenues from council tax (the residential property tax) (Heald and McLeod, 2002b).

When analysing the revenue side, the first question to ask is whether decisions on revenue affect the total amount of resources at the disposal of the devolved administration. With expenditure-based systems, the revenues raised by devolved administrations may become irrelevant in terms of total budget size because of the way in which central transfers are calculated. Accordingly, attention has to be paid as to whether a higher tax base and/or higher tax rate increases disposable resources in the hands of the devolved administration or simply leads to a reduction in central transfers.

This is particularly relevant in the case of the United Kingdom since there is no statutory entitlement to any particular level of transfers. The Barnett formula is not, for example, set out in legislation. The transfers are authorized by the normal appropriation processes of the UK Parliament, thus giving the UK government a unilateral right of determination. Instead, the arrangements for determining the financing are set out in a Treasury document (Treasury, 2002a). Certainly, the assigned revenues and EU funding reduce the central transfer. In essence, that transfer is the residual. ${ }^{13}$ However, this document, in Section 5, acknowledges that the devolved administrations have discretion over the level of self-financing, including local authority taxation. It reserves the right, however, for the UK government to take into account, in determining the assigned budget, the amount of such funding where:

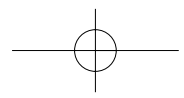


- levels of self-financed spending have grown significantly more rapidly than equivalent spending in England over a period; and

- this growth is such as to threaten targets set for the public finances as part of the management of the United Kingdom economy (Treasury, 2002a: para 5.2).

Thus the devolved administrations have a limited ability to vary local taxation, the extent of the limit being unclear and ultimately a matter for the UK government, though presumably there would be some room for negotiation.

\section{POLICY AT THE UK LEVEL}

It is essential to note the restored confidence of the UK Treasury, battered in 1992 by the United Kingdom's enforced exit from the European Monetary System, but then enjoying years of strong Chancellors of the Exchequer (Kenneth Clarke, 1993-97 and Gordon Brown, 1997-present). The resulting period of strong Treasury policy leadership, lauded in Balls and O'Donnell (2002), has seen many desirable developments, but there have been problems, inter alia, about the extent of Treasury intervention in the departmental business of Whitehall ${ }^{14}$ departments. However, the traditional distancing of the territorial departments, now reinforced by political devolution, allowed the devolved administrations to elude these problems.

Despite considerable controversy in the territories themselves and among some commentators in England - e.g. McLean (2002) and McLean and McMillan (2003) - the UK government has shown little interest in pursuing developments in the funding system beyond a modest change to the operation of the Barnett formula (Darling, 1997). ${ }^{15}$ The Darling statement on 9 December 1997 was the precursor for the formal publication in 1999 of the block rules, which had been in existence in an unpublished and less systematic form for a number of years. There has been some Parliamentary interest, with the Treasury Committee of the House of Commons conducting an inquiry in 1997 (Treasury Committee, 1997) but not going back to the topic until 2002. There has also been a low-profile inquiry into the impact of devolution, conducted by the House of Lords Select Committee on the Constitution (2003), chaired by the Lord Norton of Louth (a Conservative peer and distinguished political scientist) and which contained discussion of the funding arrangements.

In effect, the devolution financing debate has been closed down by the UK government - there were good reasons for so doing, not least the basis on which the 1997 referendums in Scotland and Wales were fought. Moreover, the devolved administrations clearly needed financial stability in 
FIGURE 4

THE SURGE IN UK PUBLIC SPENDING:

REAL YEAR-ON-YEAR CHANGES IN TOTAL DEL

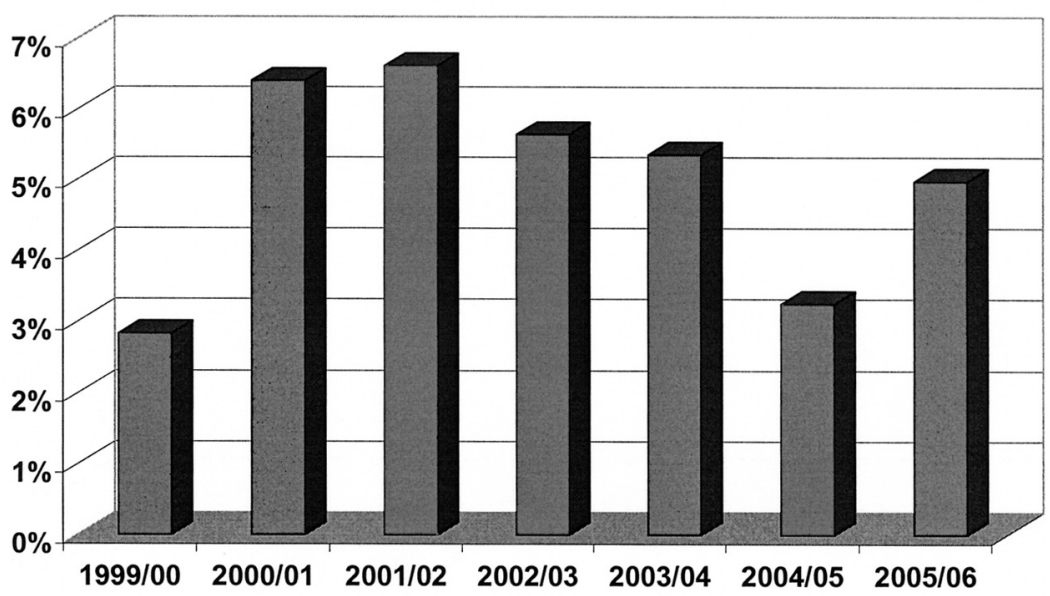

their early years, and there were complex internal political divisions within the UK government that also played a part.

The key aspect of UK policy has been the surge in real-terms public expenditure growth from 1999/2000, after low growth in 1997/98 and 1998/99, in accordance with Labour's 1997 election promises to stick to Conservative expenditure plans. Year-on-year real changes (i.e. after adjustment for changes in the GDP deflator) are shown in Figure 4. The growth rates for expenditure which is devolved or comparable to that which is devolved would certainly be higher, as a result of the priority given to education and health.

Whereas the expenditure climate has been remarkably benign to the devolved administrations, the revenue side looks markedly different. The Treasury's activism, in terms of both micro-management of the tax system and the use of tax credits to integrate UK tax and benefit systems, accentuate the difficulties that would be involved in extending the revenueraising capacities of the devolved administrations.

\section{IMPACT AT THE TERRITORIAL LEVEL}

The unprecedented growth in public expenditure in the United Kingdom has led, through the operation of the Barnett formula, to substantial - if less than in England - growth in devolved public expenditure in all three territories. 
In turn, this has led to substantial under-spending of assigned budgets, ${ }^{16}$ thereby lessening potential pressure for either tax increases or additional taxation powers.

\section{The Case of Scotland}

The distinguishing feature of the Scottish system is the tax-varying power over income tax, formally known as the Scottish variable rate of income tax, but informally as the 'tartan tax'. The Scottish Parliament made no use of this power in its first session (1997-2001), and the current First Minister (Jack McConnell) has stated that it will not do so while he holds that office (Symon, 2003).

The Scottish Parliament has the power, on passing a resolution which must be proposed by the Scottish Executive, to vary, in either direction, the 'basic rate' of income tax by up to three percentage points (in half percentage point stages), utilizing, or forgoing, the proceeds to enhance, or reduce, its spending power. ${ }^{17}$ When the provision was first enacted, the potential proceeds were $£ 150$ million for each percentage point (a total of $£ 450$ million compared to a total budget at that time of about $£ 16$ billion). There is some presumption that the yield will be index-linked and also protected against being reduced as a consequence of changes in the structure of income tax. ${ }^{18}$ In the event, changes made to the tax structure have increased the potential yield to $£ 260$ million per percentage point in 2003/04 (Treasury, 2003a: 189). ${ }^{19}$

In addition, the Scottish Parliament has the power to legislate for local taxes provided that the proceeds are used to fund local authority expenditure. That, of itself, may not be much of a constraint in that local authorities receive the bulk of their funding through transfers from the Scottish Executive, so that there is ample scope for substituting locallyraised revenue for some of these transfers. This would, of course, be subject to the general right of the UK government to reduce the central transfers in the event of sustained growth disproportionate to that in England.

While the legislation is not exactly clear, ${ }^{20}$ there is some possibility that the Scottish Parliament would be able, not just to vary the rates of existing taxes (essentially property taxes on domestic and commercial property), but to legislate to change the structure of local taxes. Accordingly, the Scottish Socialist Party has put forward proposals to replace the council tax with what it describes as a 'service tax' - in reality, a form of local income tax (Danson and Whittam, 2003). The Liberal Democrats have a UK-wide policy of abolishing the council tax and replacing it by a local income tax.

Apart from these instances, the Scottish Parliament has no power to raise taxes. It would, however, have some power to raise revenue through increasing or imposing fees and charges. This is a grey area since there is no 
case law in the United Kingdom on when a charge becomes a tax. There ought to be no legal problem provided certain conditions are met: that any charge was clearly for the provision of a service to the recipient; that there was a clear choice as to whether to acquire the service or not; and that the charge was not more than the actual cost of providing the service. Nevertheless, issues may arise as to how particular transactions are classified by the Office for National Statistics, with implications for the fiscal aggregates on which UK governments have international obligations. Realistically, the political pressures are to reduce charges rather than to increase them, and the devolved administrations may find it difficult even to maintain the real yield and the existing funding proportion (Cuthbert and Cuthbert, 2002).

As mentioned above, the tartan tax has not been used, nor is it likely to be in the foreseeable future. This is partly because of the surge in spending since 1999/2000, and partly because of a belief, especially on the part of the Labour Party, that income tax increases are electorally unpopular. The pressure for uniform levels of taxation across the United Kingdom remains strong. For example, one significant move on taxation has been to freeze the level of the business property tax for 2003/04 (Kerr, 2002; Scottish Executive, 2002), coupled with a Labour Party 2003 manifesto undertaking to peg increases for the following two years to the level of inflation. This followed complaints that business taxation levels were higher than in England. ${ }^{21}$

Despite the limited use of the powers available, there have been calls, some of them confused, for the Scottish Parliament to be given greater powers over taxation and for it to be self-financing. ${ }^{22}$ There are two distinct strands: from those essentially wishing to promote the idea of independence rather than devolution; and from those with a belief that having to live within Scotland's own taxable capacity would increase fiscal responsibility and lead to a fall in public expenditure. These calls have been linked with a debate over the economic performance of Scotland, and the related question of its falling population..$^{23}$ In that debate nationalist interests have consistently argued for the ability to set different rates of corporate taxation (despite that not being possible under EU rules unless Scotland was independent).

\section{The Case of Wales}

The financing system for the National Assembly for Wales follows a similar pattern to that for the Scottish Parliament. However, there are important differences in that the National Assembly for Wales has no power of primary legislation and no counterpart to the tartan tax. The only powers it has over revenue-raising are to set the rate of the property tax in the nondomestic sector, and to influence the rate in the domestic sector through its powers to 'cap' local authority expenditure. Any use of these powers is subject to the same caveat as in Scotland, namely that the UK government 
may reduce the assigned budget if it considered the use excessive (Treasury, 2002: para 5.2). Fiscal effort in Wales from council tax is lower than in Scotland and England, even when making adjustments for the lower average valuations.

The main financial issue in Wales since devolution has concerned 'Objective 1' funding by the EU. The normal operation of the funding rules is that assigned budgets are determined independently of EU funding. Failure to get a better deal led to the resignation of the first First Minister. Subsequently, 'above-Barnett' increases to the assigned budget were granted in Spending Review 2000 to accommodate the additional EU funding, but the matching component has to be met by the National Assembly for Wales out of its assigned budget. The political fallout on this issue was out of proportion to the relatively small sums involved.

The National Assembly for Wales has set up a Commission, chaired by Lord Richard, to look into the powers and electoral arrangements of the National Assembly. It is due to report in early 2004. ${ }^{24}$

\section{The Case of Northern Ireland}

The history of civil conflict and unrest in Northern Ireland has diverted mainland (i.e. Great Britain's) attention from two important lessons about the earlier experience of financing devolution within the United Kingdom. First, there can be a huge difference between the formal system embedded in legislation and how the system actually operates. Second, it is impossible for a poorer region to simultaneously be self-financing and to meet the expenditure requirements of a welfare state whose scale and scope are determined by practice in the more affluent regions. The failure to recognize this impossibility was extremely damaging to the former Northern Ireland Parliament (Lawrence, 1965; Green, 1979; Gibson, 1996). Intriguingly, it can be argued that all three territories now face similar issues due to contemporary increases in public expenditure, at a much faster rate than their regional economies could afford. This development greatly complicates attempts to secure a higher level of self-financing.

The Northern Ireland Assembly is able to legislate to impose taxes, but not if they are substantially the same as those in the United Kingdom as a whole. Since it is difficult to identify any substantial tax base, apart from property taxes, not already occupied by the UK government, this means, in practice, that it can legislate in detail only on property taxes (traditionally the domain of local government in Great Britain). This is currently relevant, as the Department of Finance and Personnel recently conducted an interdepartmental Review of Rating Policy (2003).

The suspension of the Assembly, for reasons entirely unconnected with fiscal matters, is now complicating financial developments. Substantial 
work has been done in Northern Ireland on a replacement for domestic rates along the lines of a capital value-based property tax, not banded like the council tax in Great Britain (Heald, 2003). Direct-rule ministers now seem to be forcing the pace on increasing fiscal effort, probably under pressure from the Treasury. However, this situation encourages Northern Ireland politicians to return to the oppositionalist politics that so characterized the earlier period of direct rule. The difficulty inherent in increasing relative fiscal effort has been highlighted by the failure to fulfil an undertaking to match or exceed council tax increases in England, because these turned out in 2003/04 vastly higher than expected. Relative fiscal effort has instead fallen. The removal of industrial derating is now scheduled for 2005..$^{25}$

A provisional needs assessment for Northern Ireland initiated by the Department of Finance and Personnel has never been published, in part because of the Assembly's suspension. However, Midwinter's evaluation of that provisional needs assessment has been published by the Assembly (Midwinter, 2002b).

\section{The Case of England}

Scotland, Wales and Northern Ireland have long had senses of territorial identity, and had these reflected in arrangements for territorial governance. There has been no English expenditure block and there has been no political entity with powers of expenditure-switching among functional programmes. Moreover, there has been no effective machinery for the coordination of public expenditure decisions so that they appear coherent at the level of the English regions. Whitehall departments with responsibility for expenditure in England have jealously protected their functional patches.

Furthermore, data on public expenditure analysed by English region have long been inadequate. Ironically, data in the early 2000s have been worse than what was available in the 1970s (Short, 1976; Short, 1978; Heald and Short, 2002). The efforts in the late 1980s (Treasury and Civil Service Committee, 1989) to secure better English regional data made no progress, as all forms of devolution were off the then Conservative government's political agenda. However, devolution has drawn more attention in England to what happens in the territories and there are now tentative proposals for regional assemblies in England (Office of the Deputy Prime Minister, 2002). ${ }^{26}$ This new interest has led to the commissioning of a study from Nuffield College (2003) on the regional analysis of public expenditure in England.

The way in which the Barnett formula operates means that the devolved administrations depend upon the formula consequences that flow from changes in comparable programmes in England. Thus far, under devolution, the leading role this gives to England has not been practically important because of the rapid growth in public expenditure as a whole, and the 
priority given, within that, to programmes such as education and health, which are devolved in the territories.

It is possible to envisage circumstances in which this arrangement could destabilize the devolved administrations. Drastic examples would include the privatization of the NHS in England, with private health insurance being subsidized by the UK tax system. The contemporary examples are much more mundane, but nevertheless important. In the early years of devolution, the devolved administrations took policy initiatives that discomforted the Whitehall departments responsible for England (Keating, 2002). For example, the Scottish Parliament abolished up-front student tuition fees, though the Scottish Executive's actual scheme was less generous to students than the proposals of the Cubie Committee (Cubie, 1999). This policy was later adopted in Wales and Northern Ireland, though the details are somewhat different. A second example is the implementation, in Scotland alone, of the proposals on free personal care for the elderly, as recommended by a UK Royal Commission (Sutherland, 1999) but rejected as too expensive by the UK Labour government. A third example is the abolition of NHS prescription charges by the National Assembly for Wales.

More recently, there are signs that Whitehall departments responsible for England are reasserting policy leadership: proposals for foundation hospitals in the NHS; proposals for top-up fees ${ }^{27}$ in English universities; and, though different in its provenance, actual congestion charging for traffic by the Greater London Authority. Because charges reduce net public expenditure, there are no formula consequences for the devolved administrations, as there would have been if the same gross expenditure had been financed by central taxation. The devolved administrations do not have sufficient financial capacities for the financing system to survive a major funding shift in England, unless they followed suit. If any expenditure becomes private, even if only notionally so, the devolved administrations would receive negative formula consequences based on the reduction in Departmental Expenditure Limits (DEL) in England, and no formula consequences thereafter. ${ }^{28}$

There are other developments in England with implications for the devolved administrations. The 2003 English local elections were marked by controversy over unexpectedly high increases in council tax, at about 13 per cent year-on-year. The outcome of the 'balance of funding review' of local government financing, currently being conducted in Whitehall, is uncertain. Another controversy during the English local elections concerned school funding, with blazing publicity about those schools that had lost money through a fundamental revision in the distribution formula. Reading the media coverage at that time made these controversies difficult to reconcile with the unprecedented growth in real public expenditure. 


\section{STRENGTHS OF THE UK SYSTEM}

The assessment of any system must turn on the extent to which it is conducive to good government. This is a wider question than the financing arrangements. A more specific question is the extent to which these arrangements contribute to, or hinder, the fiscal accountability of 'local' politicians. ${ }^{29}$ In the context of UK devolution, it is fiscal accountability at the margin (Blow, Hall and Smith, 1996) that is achievable. Full selffinancing of the devolved administrations is neither practicable (the Treasury would not relax its control over the tax system, which is also constrained by EU obligations) nor desirable (implicit territorial equalization is an ingrained feature of UK public policy)..$^{30}$

In this respect, all three territories have some fiscal authority at the margin because of the control over local taxation. Except in Northern Ireland (where local government undertakes minimal services) this alone is probably unsatisfactory since there is ample scope for confusing accountability between politicians in the devolved administrations and in local governments. The tartan tax provides, in the case of Scotland, a measure of direct accountability.

Generally, continuity has been a major strength, as there were clear limits on what changes could be absorbed before the devolved administrations were equipped to handle their side of intergovernmental financial relationships. There has been continuity, not just in the Barnett formula, but also in the discretion over allocations to the individual services. Without this fungibility, the devolved administrations might be little more than delivery agents for central government. Over 20 years, the range of functions increased and came to embrace most 'domestic' policy spending, other than social security. It is possible that the Treasury would like to erode this unconditionality, for example by extending performance-based Public Service Agreements to the devolved administrations, but it is so embedded.

Although they possess varying degrees of control over local government expenditure and finance, the three devolved administrations cannot easily be financially bypassed by the UK government. Such bypassing occurs extensively in Spain, where the central government exerts policy control over devolved services, by paying grants directly to local authorities, thereby missing out the Autonomous Communities. A somewhat different version of indirect policy control exists in Canada, where the Federal government uses its 'spending power' on functions that are devolved to the provinces, shaping policy by means of conditionality on such central transfers.

Moreover, the devolved administrations have benefited from the Treasury's biennial spending review system, which establishes figures for 
three years ahead with a firmer presumption than previously that these will not be revisited (Heald and McLeod, 2002c). This has provided them with a forward planning period and also affords them some protection from short-term macroeconomic developments; ${ }^{31}$ such protection is reasonable given the centralization of the levers of macroeconomic control in the hands of the Bank of England (monetary policy) and the Treasury (fiscal policy). Obviously, these advantages are contingent on the maintenance of the Treasury's present expenditure management system, and there is a history of periodic changes, sometimes with unintended consequences for the territorial funding system (Heald, 1994; 1995). If there were to be sudden public expenditure reductions, these would, in principle, be channelled through the Barnett formula, and not specifically targeted at the devolved administrations. $^{32}$

Caution is needed in assessing the financing system in the light of the rapid growth in public expenditure since 1999. The system has not, for this reason, been put under much pressure. In Scotland and Wales, since devolution, there have been Labour administrations, or Labour-led coalitions, coinciding with the Labour government in the United Kingdom. Difficulties will become more apparent in times of public expenditure restraint and/or when there are administrations of a substantially different political composition at the two tiers.

\section{WEAKNESSES OF THE UK SYSTEM}

Nevertheless, the Barnett formula, at least in its present form, cannot be a permanent feature, as there are limits as to how far it is desirable to take convergence of per capita public expenditure. It was originally meant as a temporary measure $;^{33}$ and lacks any underlying rationale, beyond convenience, low cost and continuity - not that these are unimportant. The continued debate over the future of the Barnett formula brings with it uncertainty. ${ }^{34}$ Moreover, the reality of the situation is that the devolved administrations would have little option but to follow the lead of a UK government were that to change significantly the funding arrangements for some service in England, for example by the introduction of substantial user charges, unless they were prepared to reduce expenditure on other services. Only Scotland has access to the tartan tax; and even that might not be sufficient.

This analysis of weaknesses is, for convenience, separated into discussion of: inadequate transparency; geographical inequity; and the absence of institutional machinery. However, there are naturally interconnections among these issues. 


\section{Inadequate Transparency}

A weakness is inadequate transparency, particularly about the numbers. Much more is now known about the process and the mechanics than was the case in the 1980s and 1990s. Improvements are coming, but these are painfully slow. The processes and definitions are well documented in the Treasury's funding policy guide, now in its third edition (Treasury, 2002); and, gradually, more numbers are becoming available, for example through the reports of the Westminster Scottish Affairs Committee (Scottish Affairs Committee, 2002a, 2002b). ${ }^{35}$ Nonetheless, the operation of the system is more complex than the simple application of the formula. Technical redefinitions and coverage changes play a significant role in the reconciliation of successive plans. Year-on-year changes are impossible to interpret without supporting calculations, and these have only just begun to be published. Information on comparable public expenditure in England (i.e. what is spent there on devolved services) is still not published in a coherent form. Notwithstanding sustained efforts, the Scottish Affairs Committee has been unable to extract these data from the UK government. ${ }^{36}$

Credit, however, is due to the Scottish Office and Scottish Executive for persisting with the annual publication Government Expenditure and Revenue in Scotland (Scottish Executive, 2003), notwithstanding the way that it has been spun by governments and attacked by opponents. The durability of this annual publication constitutes one of its strengths, as the availability of a long run of years on a reasonably comparable basis means that a clearer picture of Scottish public finances has emerged (Goudie, 2002).

\section{Geographical Inequity}

Claims abound that the Barnett formula system is 'unfair', with there being separate and unconnected debates - much of it fanciful, given the lack of information referred to above - in different parts of the United Kingdom. In England, particularly in London and the northern regions of England, the Barnett formula is blamed for treating the territories - Scotland in particular - much too generously. Lord Barnett, who as Joel Barnett was Chief Secretary to the Treasury (1974-79) and represented a northern English constituency, has on many occasions since devolution denounced the eponymous formula. In particular, he has emphasized Scotland's improvement since 1978 in terms of relative GDP (Barnett, 2001). ${ }^{37}$ In contrast, the debates in Scotland, Wales and Northern Ireland all operate on the premise that they are unjustly treated by the Barnett formula, particularly in relation to the convergence property.

Whether these allegations of injustice are well-founded depends crucially upon two unknown factors. First, as explained above, comparable 
data on devolved expenditure in the four countries of the United Kingdom are not in the public domain, though the Treasury could generate these. However, devolved expenditure per head in Scotland and Northern Ireland must be well above the corresponding England level, with Wales also above, but less so. Second, there is no contemporary evidence on what are the relative needs of the four countries: provisional estimates published in 1979 by an interdepartmental group chaired by the Treasury (Treasury, 1979) are out of date and do not relate at all closely to the mix of services now devolved.

In practical terms, even if it were to be shown that current provision for any of the devolved administrations is substantially greater than their relative need justifies, it would not be possible to make an immediate adjustment without presenting that administration with extremely difficult management and political problems - and thus destabilizing the system. There would need to be some kind of transition; and it may be the Treasury's judgement that the speed of convergence provided by the Barnett formula is as great as is practically achievable.

\section{The Absence of Institutional Machinery}

One of the obvious differentiating features of the UK devolved financing system is its informality and the absence of institutional machinery to regulate intergovernmental fiscal relationships. These gaps are understandable, given the historical development and the rapid implementation of devolution in 1999. However, in the longer term, the absence of institutional machinery will become problematic. The successful transition from administrative devolution to political devolution owes much to the public expenditure climate and the pre-eminence within the Labour government of Gordon Brown (Chancellor of the Exchequer since 1997), a Scottish politician with a long-standing commitment to devolution. Neither of these two factors will be permanent.

When the informality becomes unsustainable, certain uncomfortable facts will have to be digested. There has been a substantial loss of trust in UK government, and a loss of confidence in the competence of public authorities. The United Kingdom cannot now reliably count population, operate migration controls efficiently or collect certain taxes without the arrangements falling into disrepute because of fraud. There are complex factors at work, including demographic changes (a more fragmented household structure) and the long-term impact of the poll tax (1989-93) on public attitudes towards the state.

This context has significant implications for the nature of the devolved financing system: once confidence is lost, the scope for argument about methodology and numbers becomes immense. Accordingly, there are 
advantages in keeping whatever system is in place as simple as possible to execute, and as impervious as possible to gaming. This would be a powerful argument against abandoning a high-level mechanical formula, such as Barnett, for a complex, data-intensive exercise such as has long been carried out in Australia by the Commonwealth Grants Commission (Nicholas, 2003).

\section{CONCLUSION}

Devolution in the United Kingdom is, for the most part, recent. The exception is Northern Ireland, where there was a period of devolution for about 50 years from 1921, followed by a further quarter-century of direct rule during which the administrative apparatus of devolution was largely retained. In the other territories, administrative arrangements had evolved over the last hundred years so that, by 1999, there were government departments in the territories separate from those in the rest of the United Kingdom with a long tradition and with the ability to decide on the allocation of resources among the services for which they had responsibility.

The arrangements for political devolution, including the financial arrangements, built on this tradition of administrative devolution. This had considerable advantages in terms of: the speed with which devolution could be implemented following the 1997 election; a smooth transfer of power; and avoiding burdening the participants with too much that was new. The transition was also greatly eased by the rapid growth of public expenditure generally after 1999, leading to the devolved administrations having as much money, if not more, than they could in practice deal with.

The financial arrangements have the added advantage, at least to those administering them, of comparative simplicity. The Barnett formula, however, has become the subject of increased controversy with it being condemned, for opposite reasons, by diametrically opposed interests. (There was controversy before, but devolution has led to an increase.) Some of the debate has been uninformed, hardly surprising given the lack of transparency over the details of its operation and of reliable data on the extent of convergence. Although there are sophisticated systems of needsbased equalization in specific services within each of the countries, the Barnett formula does not provide any form of formal equalization across the countries. There are simply not enough reliable data in the public domain to enable an informed judgement as to whether it provides a reasonable proxy. There is a considerable body of opinion that the current system does not impose sufficient fiscal responsibility on politicians in the devolved administrations; and the lack of direct powers to vary taxation, except in Scotland, adds force to that. Given the surge in resources, these politicians 
have not been faced, to any great extent, with difficult choices between extra expenditure and extra taxation, and this is clearly an important consideration. It can, however, be overstated since it will always be open to politicians in devolved situations to seek to divert blame to shortcomings in the - or to the lack of an - equalization system.

In these circumstances, it seems inescapable that the Barnett formula system will need to be amended, or replaced, sooner or later. The United Kingdom, however, is not in a good position to take forward consideration of alternatives in a way that will command credibility in either the territories or the English regions. Too much is in the unfettered hands of UK government. It would, of course, be a mistake to think that there will ever be total agreement - there will always be arguments about money. But there has to be independent input into the deliberations (Heald and McLeod, 2002a).

\section{NOTES}

1. There are also long-standing arrangements for the Channel Islands and the Isle of Man.

2. There is much political sensitivity in labelling the component parts of the United Kingdom: for example, 'nation' and 'region' may be seen to carry implications for the nature of governance. When discussing England, Scotland, Wales and Northern Ireland, the Treasury's current practice of describing these as 'countries' is followed. In this article, the term 'territories' is applied to Scotland, Wales and Northern Ireland. The internal components of England are described as 'regions'. The analysis of public expenditure by country and region is referred to as 'territorial analysis'.

3. There was political devolution in Northern Ireland from 1921 until 1972. During direct rule, between 1972 and 1999, much of the administrative apparatus of devolution was retained.

4. In practice, some functions are managed on a Great Britain (GB) basis, rather than a UK basis, of which social security is one. However, the Northern Ireland social security system, separated for historical reasons, operates almost entirely in parallel with the GB system on a parity basis.

5. For reasons of space, this exposition of the funding system disregards certain details and complications; see, however, Heald and McLeod (2002a; 2002c).

6. For the politics of the use of the Barnett formula before devolution, see Mitchell (2003b). For a discussion of the system as it now operates, see Heald and McLeod (2002c).

7. In the event, the proposals, which were only for Scotland and Wales, were not proceeded with; but the Barnett formula remained, was continued by the incoming Conservative government, and extended to Northern Ireland, with effect from 1981/82.

8. This is a simplification of what actually happens. For practical reasons the adjustments are calculated at the level of UK programmes; and these are not necessarily entirely comparable. For a full explanation, see Treasury (2002a).

9. In fact, relative populations are changing. Cuthbert (2001) showed that this affects the limiting value. If relative population is declining, as in Scotland, the limiting value of the per capita expenditure index will be above 100 , the actual value varying with the rate of nominal expenditure growth.

10. See the discussion of this point in the subsection on 'Inadequate transparency'.

11. See the discussion of this point in the subsection on 'Geographical inequity'.

12. The Northern Ireland Assembly has now been suspended three times, the first two of which were brief tactical suspensions amidst political negotiations. The Assembly was again suspended from midnight on 14 October 2002, and dissolved on 28 April 2003. The Assembly elections, originally scheduled for May 2003, were held on 26 November 2003, though the Assembly was, at that time, still suspended. The Secretary of State for Northern Ireland has assumed responsibility for Northern Ireland departments. These suspensions were entirely unconnected with matters of finance. 
13. A reconciliation between the assigned budget and the central transfer can be found in the departmental reports of the relevant UK departments (Northern Ireland Office, 2003; Scotland Office, 2003; Wales Office, 2003).

14. Because many UK departments are located on or around a London street called 'Whitehall', this term is widely used to refer to UK central departments, whatever their precise location.

15. This involved annual updating of the formula proportions, using the latest available population estimates.

16. Under-spending of the assigned budgets can, under Treasury provisions applicable to all expenditure classified as Departmental Expenditure Limits (DEL), be carried forward to the following year.

17. The UK Inland Revenue would still collect the tax. If the Scottish Parliament levied an increase, the Inland Revenue would pay the proceeds to the Scottish Executive; if the Scottish Parliament decided on a reduction, the Scottish Executive would have to pay the shortfall to the Inland Revenue.

18. The legislation provided that if the UK government changed the structure of income tax, it would have to publish an assessment of the effects on the tax-varying power, and state what proposals it had so as to maintain the potential proceeds at the 1997/98 level, adjusted for inflation. Implementation of any proposals would require primary legislation by the UK Parliament. The UK government made major changes to the structure of income tax in the 1999 Budget (by lowering the starting rate but reducing the width of the starting band, while extending the basic rate band). These changes would have had the effect of raising the potential yield of the Scottish tax-varying power to $£ 230$ million per percentage point. The UK government decided, however, to take no action on this matter. However, increasing the number of potential taxpayers because of the lower threshold may also have the effect of making the power more difficult to use.

19. The real-terms yield from the tartan tax on the basis of a constant UK income tax structure would otherwise have fallen over this period as a proportion of total funding.

20. The legislation reserves to the UK Parliament all legislative powers over taxation with the exception of 'local taxes to fund local authority expenditure (for example, council tax and nondomestic rates)'. The question is whether the words in brackets are merely illustrative or whether they constrain the Scottish Parliament from making radical changes.

21. Since reforms in the early 1990 s, business property tax rates (i.e. non-domestic rates) have been uniform within each of England, Scotland and Wales (previously individual local authorities had set the rates); and for a time before and after devolution they were uniform across Great Britain. Following revaluation of the rental values on which non-domestic rates are based, tax rates in Scotland were set above those in England to maintain the yield.

22. A symposium on 'fiscal autonomy' was published in the November 2002 issue of the journal Scottish Affairs.

23. GDP in Scotland has grown more slowly than in the UK; but growth of GDP per head is broadly comparable (McLaren, 2003).

24. Details of the terms of reference, membership, and evidence received are available on the Commission website (www.richardcommission.gov.uk).

25. This only became a revenue loss to the assigned budget after Spending Review 2000, whereas previously it was costless to Northern Ireland programmes.

26. However, the major functional spending areas of health and education are outside the proposed competence of English regional assemblies.

27. This terminology relates to the proposal in a White Paper published by the Secretary of State for Education and Skills, whose remit extends practically only to England, that English universities would be able to charge students differential fees up to a ceiling, presently proposed to be $£ 3,000$ per annum. These proposals, which are very controversial in England, are unlikely to be adopted by the devolved administrations.

28. Whatever policy initiatives are taken in England, the key question for the devolved administrations is whether the expenditure remains within DEL, in which case formula consequences are not affected. If, however, the expenditure is transferred to Annually Managed Expenditure (AME), there are no automatic formula consequences and this becomes a matter of bilateral negotiation with the Treasury (Heald and McLeod, 2002c).

29. The authors have some difficulty with the term 'accountability' in this context, both because politicians can be accountable in a technical sense without being responsible for raising the 
finance and because the term is frequently misused. Nonetheless, it is in common use.

30. For further discussion of these issues, see Heald and McLeod (2002b).

31. This mechanism provides a floor to increases in assigned budgets. Public expenditure forms a significantly larger proportion of GDP in the territories than it does in England. Therefore slower relative growth of a larger component is magnified, an effect potentially reinforced if faster nominal expenditure growth in England produced higher real wages and attracted employees from the territories. On the macroeconomic issues, see McCrone (1999) and Ferguson et al. (2003).

32. However, section 9.4i of the Funding Policy document (Treasury, 2002a) contains a provision, carried forward from the earlier block rules, allowing for across-the-board adjustments in devolved programmes. This relates to instances when the UK government decides to make a uniform general adjustment to public spending programmes across departments.

33. The long-term survival of temporary funding formulae is not, however, new. A predecessor, the Goschen formula, survived for nearly a century (Mitchell, 2003a).

34. The present authors return to the alternatives to, or possible development of, the Barnett formula, as well as the separate, but related, question of alternative funding arrangements, in another paper (Heald and McLeod, 2003). For a discussion of how a needs-weighted Barnett formula might operate, see Heald and McLeod (2002a).

35. Evidence that the Treasury is not willing to release data on expenditure in England comparable to that expenditure which is devolved can be found in the reports of the Scottish Affairs Committee (2002a; 2002b). Even if data are not readily available, they could be made available.

36. See Scotland Office (2002).

37. Heald and McLeod (2002a) disputed the relevance of relative GDP to a formula that determines changes in the funding of services such as education and health.

\section{REFERENCES}

Balls, Edward and Gus O'Donnell (eds.) (2002), Reforming Britain's Economic and Financial Policy: Towards Greater Economic Stability. Basingstoke: Palgrave.

Barnett, Lord Joel (2001), speech in House of Lords debate on the Barnett formula, 7 November, House of Lords Official Report, Cols.225-9. London: Stationery Office.

Bell, David and Alex Christie (2001), 'Finance - The Barnett Formula: Nobody's Child?' in A. Trench (ed.), The State of the Nations 2001: The Second Year of Devolution in the United Kingdom. Thorverton: Imprint Academic, pp.135-51.

Bell, David, Sheila Dow, David King and Neil Massie (1996), Financing Devolution (Hume Papers on Public Policy, Vol.4, No.2). Edinburgh: Edinburgh University Press.

Blow, Laura, John Hall and Stephen Smith (1996), Financing Regional Government in Britain (IFS Commentary No.54). London: Institute for Fiscal Studies.

Cubie, Andrew (chair) (1999), Student Finance: Fairness for the Future - Report of the Independent Committee of Inquiry into Student Finance. Edinburgh: Scottish Executive.

Cuthbert, Jim (2001), 'The Effect of Relative Population Growth on the Barnett Squeeze', Fraser of Allander Institute Quarterly Economic Commentary, Vol.26, No.2, pp.34-7.

Cuthbert, Jim and Margaret Cuthbert (2001), 'The Barnett Squeeze in Spending Review 2000', Fraser of Allander Institute Quarterly Economic Commentary, Vol.26, No.2, pp.27-33.

Cuthbert, Jim and Margaret Cuthbert (2002), 'The Treasury Funding Statements as a Tool for Monitoring the Devolution Settlement', Fraser of Allander Institute Quarterly Economic Commentary, Vol.27, No.4, pp.32-9.

Danson, Mike and Geoff Whittam (2003), Paying for Local Government, Water and Sewerage Services Fairly: The Case For a Scottish Service Tax and a Scottish Water Charge. Paisley: Department of Economics and Enterprise, University of Paisley.

Darling, Alistair (1997), Hansard, 9 December, Cols.510-13W. London: Stationery Office.

Department for Education and Skills (2003), The Future of Higher Education, Cm. 5735. London: Stationery Office.

Ferguson, Linda, David Learmonth, Peter McGregor, Kim Swales and Karen Turner (2003). The Impact of the Barnett Formula on the Scottish Economy: Endogenous Population and the 
Darling Amendment. Glasgow: Department of Economics, University of Strathclyde, mimeo.

Gibson, Norman (1996), 'Northern Ireland and Westminster: Fiscal Decentralisation - a Public Economics Perspective', in Northern Ireland Economic Council (ed.), Decentralised Government and Economic Performance in Northern Ireland (Occasional Paper 7). Belfast: Northern Ireland Economic Council, pp.10-89.

Goudie, Andrew (2002), 'GERS and Fiscal Autonomy', Scottish Affairs, No.41, pp.56-85.

Green, Arthur (1979), Devolution and Public Finance: Stormont from 1921 to 1972 (Studies in Public Policy No.48). Glasgow: Centre for the Study of Public Policy, University of Strathclyde.

Heald, David (1994), 'Territorial Public Expenditure in the United Kingdom', Public Administration, Vol.72, No.2, pp.147-75.

Heald, David (1995), 'Steering Public Expenditure with Defective Maps', Public Administration, Vol.73, No.2, pp.213-40.

Heald, David (1996), 'Formula-controlled Territorial Public Expenditure in the United Kingdom', Public Finance/Finances Publiques, Vol.46, No.4, pp.534-58.

Heald, David (2003), Funding the Northern Ireland Assembly: Assessing the Options (Research Monograph 10). Belfast: Northern Ireland Economic Council.

Heald, David and Neal Geaughan (1997), 'The Tartan Tax: Devolved Variation in Income Tax Rates', British Tax Review, No.5, pp.337-48.

Heald, David and Alasdair McLeod (2002a), 'Beyond Barnett? Funding Devolution', in P. Robinson and J. Adams (eds.), Devolution in Practice. London: Institute for Public Policy Research, pp.147-75.

Heald, David and Alasdair McLeod (2002b), 'Fiscal Autonomy under Devolution: Introduction to Symposium', Scottish Affairs, No.41, pp.5-25.

Heald, David and Alasdair McLeod (2002c), 'Public Expenditure', in The Laws of Scotland: Stair Memorial Encyclopaedia - Constitutional Law Volume. Edinburgh: LexisNexis Butterworths, paras 480-551.

Heald, David and Alasdair McLeod (2003), Scotland's Fiscal Relationships with England and the United Kingdom, paper given at the 'Union of the Crowns' Conference, 6-7 November. Edinburgh: British Academy/Royal Society of Edinburgh, mimeo.

Heald, David and John Short (2002), 'The Regional Dimension of Public Expenditure in England', Regional Studies, Vol.36, No.7, pp.743-55.

House of Lords Select Committee on the Constitution (2003), Devolution: Inter-Institutional Relations in the United Kingdom, Second Report of Session 2002-03 (House of Lords Paper 28). London: Stationery Office.

Keating, Michael (2002), 'Devolution and Public Policy in the United Kingdom: Convergence or Divergence?', in P. Robinson and J. Adams (eds.), Devolution in Practice. London: Institute for Public Policy Research, pp.3-21.

Kerr, Andy (2002), 'Local Government Finance Allocations', Scottish Parliament Official Report, 4 December, Cols.15973-84.

Kilbrandon Royal Commission on the Constitution (1973), Royal Commission on the Constitution, 1969-1973: Report, Cmnd. 5460; Memorandum of Dissent, Cmnd. 5460-i. London: HMSO

Lawrence, Reginald (1965), The Government of Northern Ireland: Public Finance and Public Services 1921-1964. Oxford: Clarendon Press.

McCrone, Gavin (1999), 'Scotland's Public Finances from Goschen to Barnett', Fraser of Allander Institute Quarterly Economic Commentary. Vol.24, No.2, pp.30-46.

McLaren, John (2003), 'Scotland's Improving Economic Performance: a Long-Term Comparative Study', Fraser of Allander Institute Quarterly Economic Commentary. Vol.28, No.2, pp.42-8.

McLean, Iain (2002), 'Memorandum', in House of Lords Select Committee on the Constitution, Devolution: Inter-Institutional Relations in the United Kingdom - Evidence Complete to 10 July 2002 (House of Lords Paper 147 of Session 2001-02), London: Stationery Office, pp.422-7.

McLean, Iain and Alistair McMillan (2003), 'The Distribution of Public Expenditure across the UK Regions', Fiscal Studies, Vol.24, No.1, pp.45-71.

Midwinter, Arthur (2002a), 'The Limits to Fiscal Autonomy under the Devolution Settlement', Scottish Affairs, No.41, pp.102-120.

Midwinter, Arthur (2002b), Northern Ireland's Expenditure Needs: a Preliminary Assessment (Research Paper 81/02). Belfast: Northern Ireland Assembly.

Mitchell, James (2003a), Governing Scotland: The Invention of Administrative Devolution. 
Basingstoke: Palgrave Macmillan.

Mitchell, James (2003b), 'Spectators and Audiences: The Politics of UK Territorial Finance', Regional and Federal Studies, Vol.13, No.3, pp.7-21.

Nicholas, Malcolm (2003), 'Financial Arrangements between the Commonwealth Government and Australian States', Regional and Federal Studies, Vol.13, No.3, pp.151-80.

Northern Ireland Office (2003), Northern Ireland Office 2003 Departmental Report, Cm. 5929. London: Stationery Office.

Nuffield College (2003), Identifying the Flow of Domestic and European Expenditure into the English Regions. Oxford: Nuffield College, Oxford and London: Office of the Deputy Prime Minister.

Office of the Deputy Prime Minister (2002), Your Region, Your Choice: Revitalising the English Regions, Cm. 5511. London: Stationery Office.

Review of Rating Policy (2003), The Rating of Vacant Property and the Removal of Industrial Derating. Bangor, Northern Ireland: Department of Finance and Personnel.

Scotland Office (2002), 'Supplementary Memorandum to the Scottish Affairs Committee', in Scottish Affairs Committee, Scotland Office Expenditure, First Special Report of Session 2002-03, HC 198. London: Stationery Office, pp.7-13.

Scotland Office (2003), Departmental Report 2003, Cm. 5927. Edinburgh: Stationery Office.

Scottish Affairs Committee (2002a), Minutes of Evidence Taken Before the Scottish Affairs Committee, Wednesday 7 November 2001, Session 2001-02, HC 345-i. London: Stationery Office.

Scottish Affairs Committee (2002b), Scotland Office Expenditure, First Special Report of Session 2002-03, HC 198. London: Stationery Office.

Scottish Executive (2002), 'Business Rates Frozen for 2003-04', Finance and Public Services press release, 4 December. Edinburgh: Scottish Executive.

Scottish Executive (2003), Government Expenditure and Revenue in Scotland 2000-2001, SE/2003/4. Edinburgh: Scottish Executive.

Short, John (1976), Public Expenditure in the Northern Region and Other British Regions (Technical Report No.12). Newcastle-upon-Tyne: Northern Region Strategy Team.

Short, John (1978), 'The Regional Distribution of Public Expenditure in Great Britain 1969/70-1973/74', Regional Studies, Vol.12, No.5, pp.449-510.

Sutherland, Sir Stewart (chair) (1999), With Respect to Old Age: Long Term Care - Rights and Responsibilities, Report of the Royal Commission on Long Term Care, Cm 4192-I. London: Stationery Office.

Symon, Ken (2003), 'First Minister in “Crystal Clear” Promise', Sunday Herald, 31 August.

Treasury (1979), Needs Assessment Study: Report. London: HM Treasury.

Treasury (2001), Public Expenditure: Statistical Analyses 2001-02, Cm. 5101. London: Stationery Office.

Treasury (2002a), Funding the Scottish Parliament, National Assembly for Wales and Northern Ireland Assembly: A Statement of Funding Policy, 3rd edition. London: HM Treasury.

Treasury (2002b), Public Expenditure: Statistical Analyses 2002-03, Cm. 5401. London: Stationery Office.

Treasury (2003a), Budget 2003: Building a Britain of Economic Strength and Social Justice Economic and Fiscal Strategy Report and Financial Statement and Budget Report, HC 500 of Session 2002-03. London: Stationery Office.

Treasury (2003b), Public Expenditure: Statistical Analyses 2003, Cm. 5901. London: Stationery Office.

Treasury (2003c), Public Expenditure: Statistical Analyses 2003 - Corrigendum: Corrected Tables for Chapter $8, \mathrm{Cm}$. 5901. London: Stationery Office.

Treasury and Civil Service Committee (1989), The Presentation of Information on Public Expenditure, Sixth Report of Session 1988-89, HC 217. London: HMSO.

Treasury Committee (1997), The Barnett Formula, Second Report of Session 1997-98, HC 341. London: Stationery Office.

Wales Office (2003), Departmental Report of the Wales Office, Cm. 5928. London: Stationery Office. 